\title{
The Understanding of Pre-Service Physics Teachers on Electric Circuit Concept
}

\author{
Anita $^{a}$, Sy. Lukman Hakim Assagaf, Boisandi \\ IKIP PGRI Pontianak, Jalan Ampera No.88 Pontianak, Indonesia \\ a)anitaummufaqih@gmail.com
}

\begin{abstract}
The purpose of this research was to find out the descriptive of pre-service physics teachers understanding of the concept of electrical circuits, especially in the characteristic of series circuits and parallel circuits. The method used in this research was a descriptive method. The sample of this research was the fourth-grade students who took Basic Electronics course. The primary data of this research collected from the students' test consisted of 12 multiple choices. Data analysis concluded that the student's understanding of the concept of the electric circuit was low, with an average percentage of total indicators of $84.4 \%$.
\end{abstract}

Keywords: pre-service physics teachers' understanding, electric circuit concept

\section{INTRODUCTION}

Teachers are professional educators who have a role to educate, teach, guide, train and evaluate their students by their competencies. The teacher is one factor in the success of education. The ability that must be possessed by professional teachers is master the material (understanding material concepts). With the ability to understand concepts, teachers can understand concepts, the relationship between related subjects, and apply scientific concepts in everyday life (Purwoko 2017). Besides, the teacher can obtain knowledge from the various information that is around him through observation (Kholidah \& Sujadi 2018).

Therefore, the learning objectives can appropriately be realized, prospective teacher students, especially physics teachers, are required to master the material concepts that will be delivered to their students. These concepts and their relevance are expected to be able to be used by students in solving problems encountered in their daily lives (Pateda, Kendek, \& Saehana 2015, 13-17).

Physics learning is a means to develop and train students to be able to master the knowledge, concepts, and principles of physics, and have scientific skills (Yolanda, Syuhendri, \& Andriani 2016). One is the concept of electric circuits. This concept is a concept that will influence the following theories. In these concept students or prospective students tend to have difficulty understanding because the characteristics of this concept are abstract, which is difficult to be observed directly with the five senses (Falah 2018). The results of the research by Nugraeni (2013, 12-16) state that in the dynamic electrical matter, it found that $55 \%$ of students did not understand the concept of series current and $57 \%$ in the theory of parallel circuits and both on the current and voltage material (Iftitah research et al. 2017).

Based on this background, this study was conducted to determine the understanding of the concept of prospective physics students in electrical circuit material. The results of this study can become a foundation for educators in determine the learning strategies appropriately. 


\section{RESEARCH METHODOLOGY}

This research uses a descriptive method. The subjects of this study were fifth-semester students who took basic electronic practicum courses for the 2017-2018 school year totaling 15 people. The research data was obtained using multiple-choice test questions accompanied by reasons. The questions given are 12 with six question indicators.

Data from student answers are then analyzed and classified into two criteria, namely understanding the concept and not understanding the concept. The criteria for students who do not understand the concept if:

a. The answer given is correct, but the reason is wrong;

b. The answer to the wrong, and the reason is right;

c. The wrong answers and reasons;

d. Not answer one or both.

After being analyzed and classified based on conceptual understanding criteria, the research data in the form of student answers then calculated the average percentage for each indicator and the overall percentage average and categorized according to TABLE 1.

TABLE 1. Level of understanding

\begin{tabular}{cc}
\hline Percentage & Category \\
\hline $1 \leq 30 \%$ & Low \\
$30 \leq 60 \%$ & Middle \\
$60 \leq 100 \%$ & High \\
\hline
\end{tabular}

\section{RESULTS AND DISCUSSION}

The results of the study obtained data on the category of student understanding for each indicator in detail can be seen in TABLE 2. The results of the study showed that six indicators of understanding the concepts provided by all students were in a low category.

TABLE 2. Concept understanding criteria

\begin{tabular}{|c|c|c|c|c|}
\hline \multirow{2}{*}{$\begin{array}{l}\text { Indicator } \\
\text { Indicator } 1\end{array}$} & \multicolumn{2}{|l|}{ Criteria } & \multirow{2}{*}{$\begin{array}{l}\text { Percentage } \\
27\end{array}$} & \multirow{2}{*}{$\begin{array}{l}\text { Category } \\
\text { Low }\end{array}$} \\
\hline & Understand the concept & & & \\
\hline & Not understand the concept & 73 & & \\
\hline \multirow[t]{2}{*}{ Indicator 2} & Understand the concept & & 7 & Low \\
\hline & Not understand the concept & 93 & & \\
\hline \multirow[t]{2}{*}{ Indicator 3} & Understand the concept & & 7 & Low \\
\hline & Not understand the concept & 93 & & \\
\hline \multirow[t]{2}{*}{ Indicator 4} & Understand the concept & & 3 & Low \\
\hline & Not understand the concept & 97 & & \\
\hline \multirow[t]{2}{*}{ Indicator 5} & Understand the concept & & 30 & Low \\
\hline & $\begin{array}{l}\text { Not understand the concept } \\
\text { Understand the concept }\end{array}$ & 70 & 20 & Low \\
\hline Indicator 6 & Not understand the concept & 80 & & \\
\hline On average & ey don't understand the conce & & 84.4 & Low \\
\hline
\end{tabular}

In TABLE 2, the percentage of not understanding the first highest concept of $97 \%$ lies in the fourth indicator of the concept of flow in parallel circuits. The concept of current flowing in parallel circuits is that the current will be divided into each branch because parallel circuits are current dividers. The amount of current flowing in parallel circuits is different depending on how much 
resistance is given to each component that exists. It found that most of them did not answer and some students answered not following the questions, which can be seen in FIGURE 1a, that in a parallel circuit the inflows are the same as outflows, this concept is generally correct, but does not answer the questions given. As well as other answers are wrong in the operation of mathematics (FIGURE 1b).

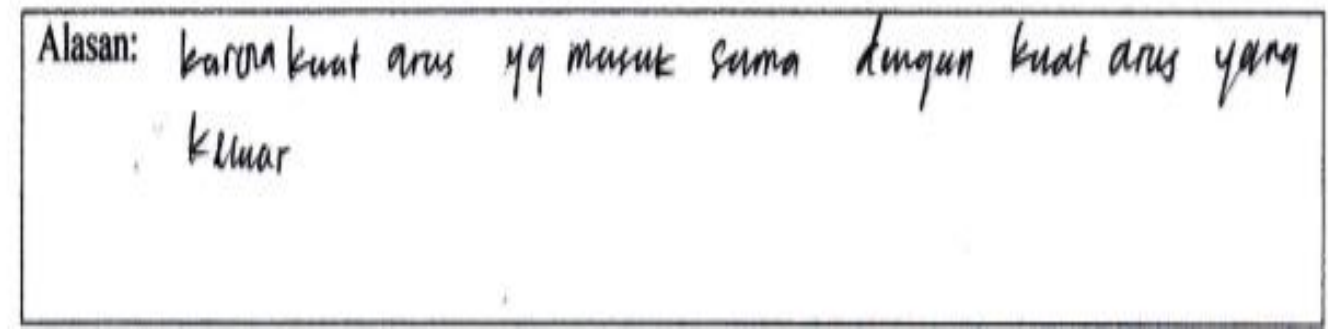

a)

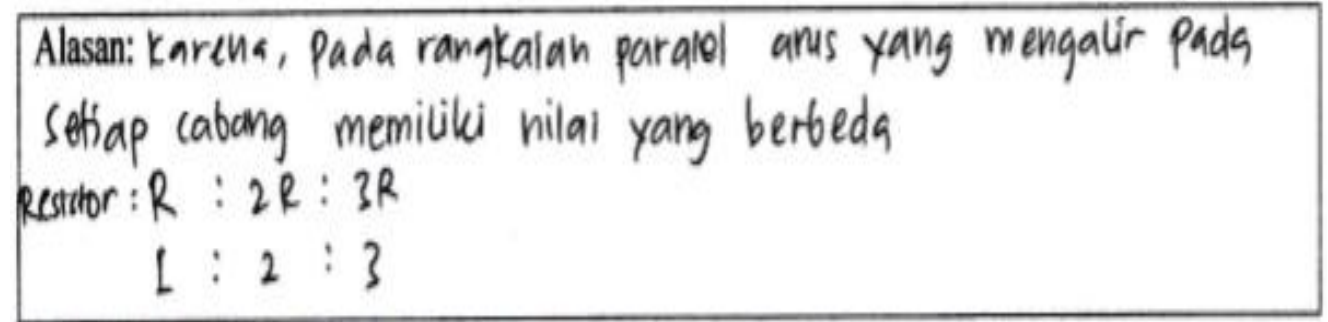

b)

FIGURE 1. The snapshot of the response for the fourth indicator.

The low understanding of the concept (not understanding the concept) is the second and third indicators of $93 \%$. The second indicator is the concept of voltage in parallel circuits. In parallel circuits, the voltage across each branch is equal. The FIGURE 2.a, the student answers that the greater the voltage is given, the greater the resistance. In FIGURE 2b, the student answers that the stress on each obstacle is the same, but in mathematical operation add up the existing voltage. This is not following the concept.

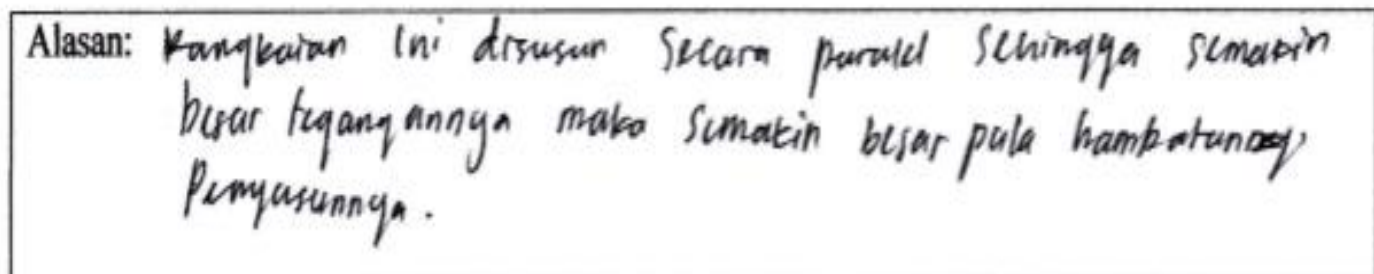

a)

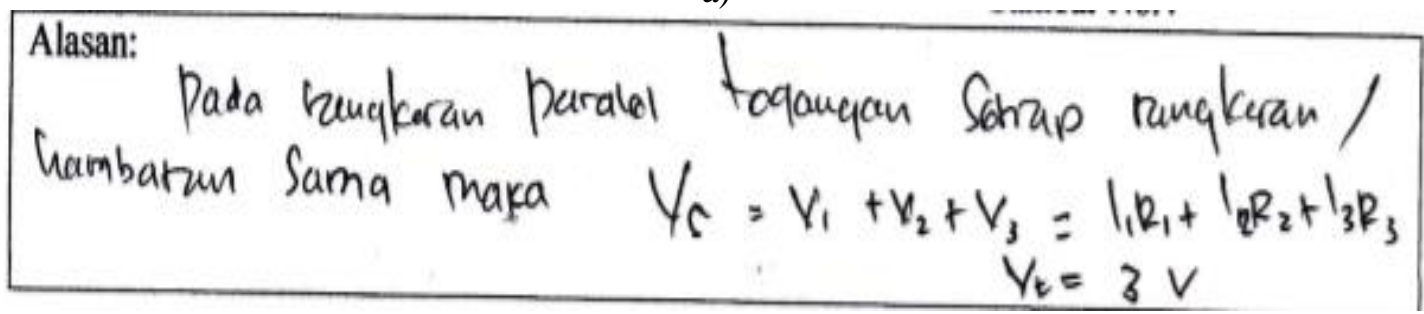

b)

FIGURE 2. The snapshot of the answer for the second indicator.

In the third indicator, which is about determining the concept of voltage in series. The characteristic of a series is a voltage divider, so the amount of voltage given will be distributed according to the amount of voltage that exists. The results of the student answer sheet analysis found that students did not answer choices or did not write down reasons. Whereas in FIGURE 3, it can be 
seen that students answer the series of obstacles that flow in each series are the same. In the series, the series is not an obstacle of the same magnitude, but a large flowing current of equal magnitude.

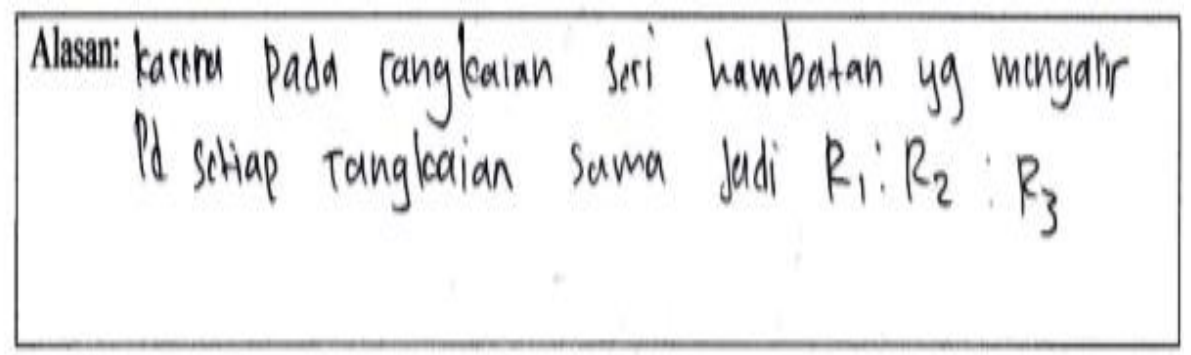

FIGURE 3. Snapshot of the answer for the third indicator

On the sixth indicator with a large understanding of the concept by $80 \%$, which is to determine the concept of equivalent value substitute barriers in parallel circuits. To find the equivalent value in a parallel circuit using the following EQUATION (1).

$$
\frac{1}{R e q}=\frac{1}{R_{1}}+\frac{1}{R_{2}}+\ldots+\frac{1}{R_{n}}
$$

The results of the answers found that most did not answer choices and also did not give reasons. Besides, as shown in FIGURE 4, students are wrong in using formulas to find the barrier resistance values in parallel circuits. Incorrect use of equations can be caused students do not understand the existing concepts nor do they understand the operation of fraction mathematics.

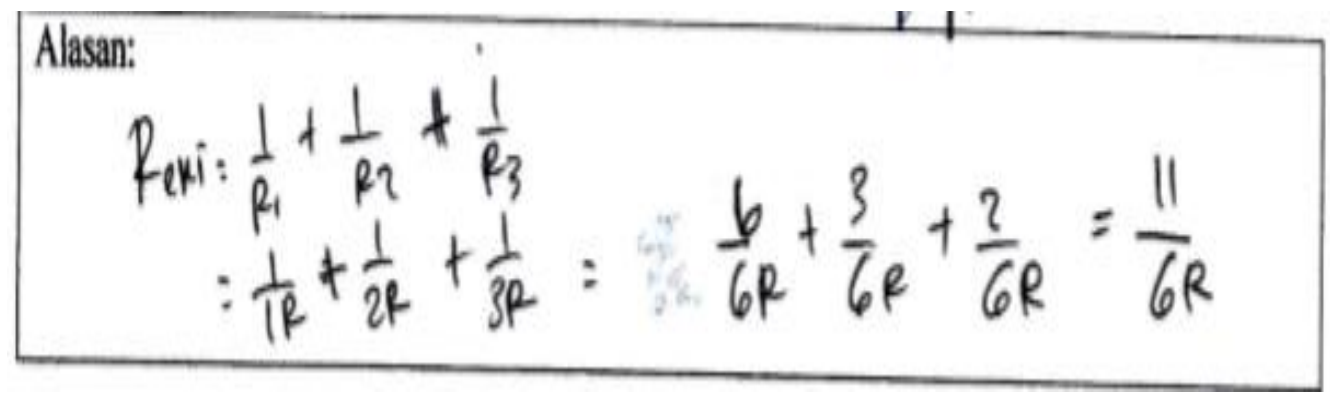

FIGURE 4. The snapshot of the answer for the sixth indicator.

FIGURE 5, is a snapshot of the response to the first indicator, which is determining the electric current in the series. The characteristics of a series are that the current flowing in each component is the same. In FIGURE 5, students see that the current strength in the series is the same, but uses the value of comparison in the operation of mathematics, so that the concept of flows of equal value is not met.

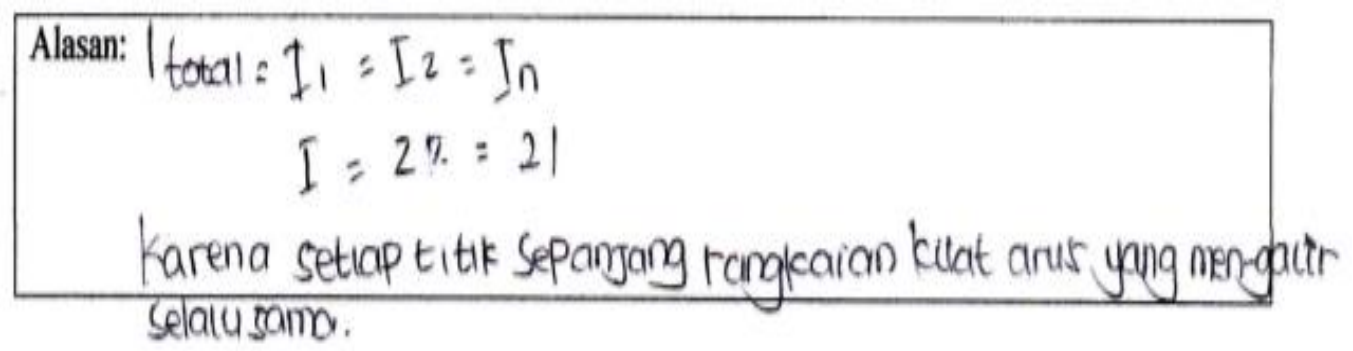

FIGURE 5. The snapshot of the answer for the first indicator.

In FIGURE 6, you can see a snapshot of the student's answer to the fifth indicator, determining the concept of equivalent values of substitute barriers on the series sequence. To find a substitute (equivalent) value in a series, EQUATION 2 can be used as follows:

$$
R_{e q}=R_{1}+R_{2}+\ldots+R_{n}
$$


The results of the student answers were obtained that students could not understand the concept of the series resistance correctly, so it was still wrong to find the equivalent value in the series. Both images (FIGURES $6 \mathrm{a}$ and $6 \mathrm{~b}$ ), the two images are formulas to find equivalent values in parallel sequences.

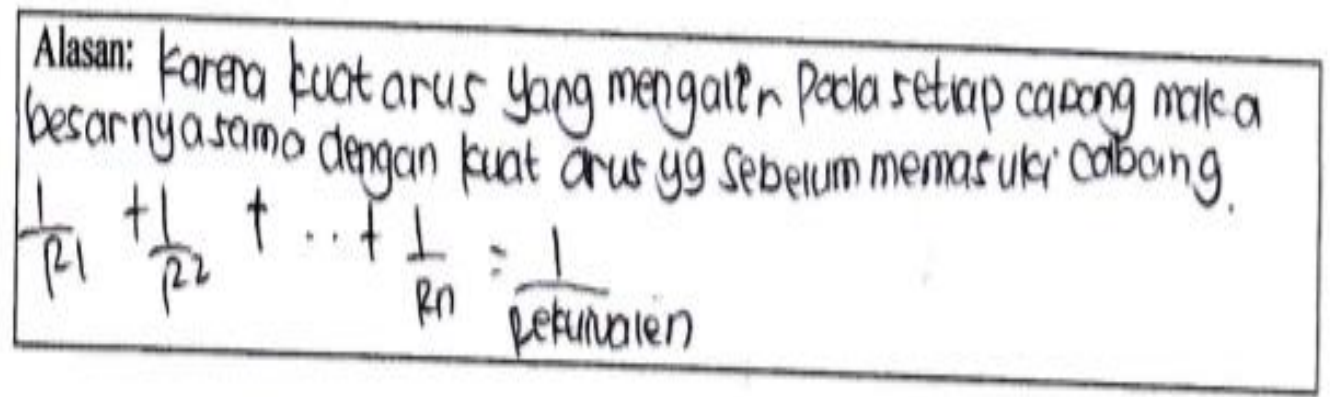

a)

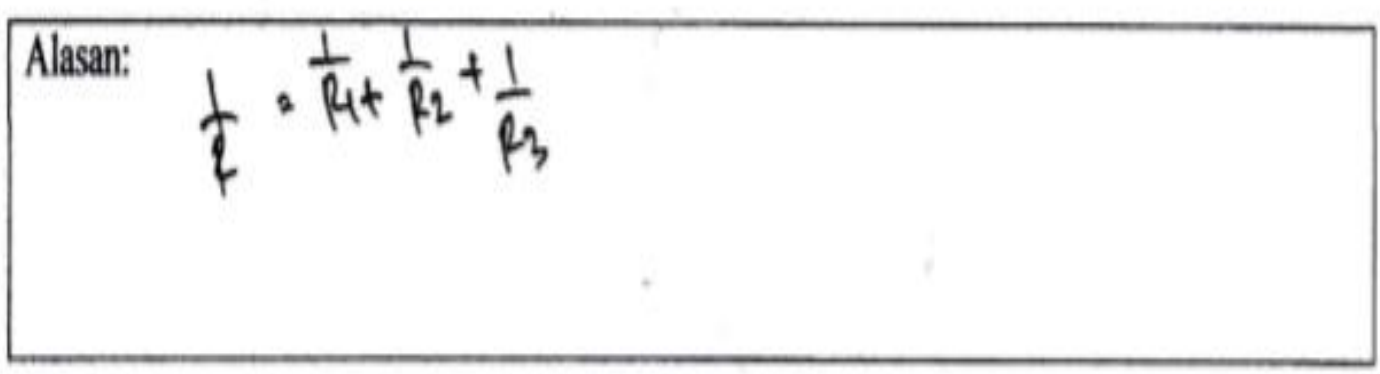

b)

FIGURE 6. The snapshot of the answer for the fifth indicator.

The ability to understand concepts is needed by prospective teacher students to achieve educational goals in the learning and learning process. If the prospective teacher does not master the concept correctly, it will certainly have an impact on the students later.

In this study, prospective teacher students are said to understand the concept being tested if the answers and reasons given are correct. This is because if students understand the concept, they can correctly re-explain the concepts in their own words and be able to associate with other related concepts. The results of the analysis obtained that the ability to understand the concept of electrical circuits of prospective physics teacher students is low.

Data from the research on the understanding of the concept of student physics teacher candidates in the concept of electric power is in the basic electronics course. Mastery of concepts is the ability to explain, interpret, analyze, and apply physical concepts in solving problems of physics (Iftitah et al. 2017). So that when the student answers not by the question or does not answer, it is assumed that the student does not understand the concept being tested.

\section{CONCLUSIONS}

Based on the results of the analysis of the test of the ability to understand the concept of electrical circuits of prospective physics teacher students, it can be concluded that the understanding ability of the concept of physics teacher students to the concept of electrical circuit characteristics is still low with an average percentage of $84.4 \%$. The percentage of conceptual understanding for each indicator is:

a. Determine the electric current in the series circuit by $73 \%$

b. Determine the voltage on the parallel circuit by $93 \%$

c. Determine the voltage in the series circuit by $93 \%$

d. Determine the electric current in a parallel circuit of $97 \%$

e. Determine the equivalent value of the replacement obstacle in the series of $70 \%$

f. Determine the equivalent value of substitute barriers on parallel sequences $80 \%$ 


\section{REFERENCES}

Falah, HW 2018, 'Remediasi Kesalahan Siswa SMA Mengerjakan Soal-Soal Rangkaian Listrik Arus Searah Melalui Model Pembelajaran Twa.', https://media.neliti.com/media/publications/214712remediasi-kesalahan-siswa-sma-mengerjaka.pdf

Iftitah, AN, Prastowo, SHB, Harijanto, A 2017, ' Anaslisis Penguasaan Konsep Rangkaian Arus Bolak-Balik Pada Siswa Kelas XII SMA,' Seminar Nasional Pendidikan Fisika 2017, ISSN : $2527-5917$, vol.2

Kholidah, IR, dSudaji, AA 2018, 'Analisis Pemahaman Konsep Matematika Siswa Kelas V Dalam Menyelesaikan Soal Di SD Negeri Gunturan Pandak Bantul Tahun Ajaran 2016/2017', Jurnal Pendidikan Ke-SD-an, vol. 4, no. 3, pp. 428-431

Nugraeni, D, Jamzuri, Sarwanto 2013, 'Penyususnan Tes Diagnostik Fisika Materi Listrik Dinamis.' Jurnal Pendidikan Fisika, vol. 1, no. 2, pp.12-16

Pateda, AB, Kendek, Y, Saehana, S 2015, 'Analisis Pemahaman Konsep Magnet Mahasiswa Calon Guru Fisika,' Jurnal Pendidikan Fisika Tadulako, vol. 3, no. 2, pp. 13-17

Purwoko, RY 2017, 'Analisis Kemampuan Content Knowledge Mahasiswa Calon Guru Matematika Pada Praktek Pembelajaran Mikro,' Jurnal Pendidikan Surya Edukasi, vol.3, no.1, pp.55-65.

Yolanda, R, Syuhendri, Andriani, N 2016, 'Analisis Pemahaman Konsep Siswa SMA Negeri Sekecamatan Ilir Barat I Palembang pada Materi Suhu dan Kalor dengan Instrumen TTCI dan CRI', Jurnal Inovasi dan Pembelajaran Fisika, vol.3, no.1, pp.1-13 